\title{
Faktor - Faktor yang Berhubungan dengan Konsumsi Buah-Sayur pada Remaja di Daerah Rural-Urban, Yogyakarta
}

\author{
Alfonsa Reni Oktavia ${ }^{1}$, Ahmad Syafiq ${ }^{2}$, Asih Setiarini ${ }^{3}$ \\ 'Program Studi DIII Keperawatan, STIKes Pertamedika, Jakarta, Indonesia \\ ${ }^{2,3}$ Departemen Gizi Kesehatan Masyarakat, Fakultas Kesehatan Masyarakat, Universitas \\ Indonesia, Depok, Indonesia \\ alfonsareni2710@gmail.com
}

\begin{abstract}
Vegetable consumption of the Indonesian population is still low in the teen age group both in rural and urban areas. Consumption of fruits and vegetables in adolescents is important for preventing degenerative diseases. The aim of the study was to determine the factors associated with fruit and vegetable consumption in adolescents in rural-urban areas. This study used a cross-sectional research design in Yogyakarta with 196 rural-urban teens. The analysis used was univariate, bivariate, analysis. The results showed that teenagers in urban areas ate less vegetables. Whereas in teenagers in rural areas, they consume less fruit. There is a significant relationship between vegetable consumption in adolescents in rural areas with father's education level $(p=0.031)$ and self-image perception $(p=0.041)$, while in urban areas there is a significant relationship between vegetable consumption and self-image perception $(p=0.049)$ and education in adolescents $(p=0.047)$. Fruit consumption in adolescents in rural areas that are significantly related is the perception of body image $(p=0.016)$, while in adolescents in urban areas that are significantly related is monthly money $(p=0.003)$. Suggestions that can be given are provide health education about the importance of the benefits of vegetables and fruit.
\end{abstract}

Keyword: fruit-vegetable consumption, adolescent, rural-urban

\begin{abstract}
Abstrak
Konsumsi sayur-buah penduduk Indonesia masih rendah pada kelompok usia remaja baik di daerah rural dan urban. Konsumsi buah dan sayur pada remaja adalah hal yang penting untuk mencegah munculnya penyakit degeneratif. Tujuan penelitian untuk mengetahui faktor-faktor yang berhubungan dengan konsumsi buah dan sayur pada remaja di daerah rural dan urban. Penelitian ini menggunakan desain penelitian cross sectional di Yogyakarta dengan jumlah 196 remaja rural dan urban. Uji Statistik yang digunakan adalah dengan uji chi-square. Hasil penelitian menunjukkan remaja di daerah urban frekuensikonsumsi sayuran kurang dari 3 kali/hari, sedangkan pada remaja di daerah rural, frekuensi konsumsi buah kurang dari 3 kali/hari. Terdapat hubungan yang signifikan antara konsumsi sayuran pada remaja didaerah rural dengan tingkat pendidikan ayah $(\mathrm{p}=0,031)$ dan persepsi citra diri $(\mathrm{p}=0,041)$, adapun di daerah urban ada hubungan yang signifikan antara konsumsi sayuran dengan persepsi citra diri $(\mathrm{p}=0,049)$ dan pendidikan pada remaja $(\mathrm{p}=0,047)$. Konsumsi buah pada remaja di daerah rural yang berhubungan signifikan adalah persepsi citra tubuh $(\mathrm{p}=0,016)$, sedangkan pada remaja di daerah urban yang berhubungan secara signifikan adalah uang bulanan $(p=0,003)$. Saran yang dapat diberikan yaitu perawat bekerjasama dengan institusi pendidikan memberikan pendidikan kesehatan kepada remaja tentang pentingnya manfaat sayur dan buah.
\end{abstract}

Kata kunci: konsumsi buah-sayur, remaja, rural-urban

Jurnal Keperawatan Raflesia, Volume 1 Nomor 1, Mei 2019

ISSN: 2656-6222, DOI 10.33088/jkr.vlil.400

Available online: https://jurnal.poltekkes-kemenkes-bengkulu.ac.id/index.php/jkr 


\section{PENDAHULUAN}

Peningkatan konsumsi buah dan sayur hingga $600 \mathrm{~g}$ per hari dapat mengurangi penyakit di seluruh dunia sebesar $1,8 \%$, serta mengurangi beban penyakit jantung iskemik sebesar 31\%, stroke iskemik sebesar 19\%, kanker perut sebesar 19\%, penyakit esophagus $20 \%$, penyakit paruparu 12\%, dan kolorektal 2\% (Karen L, et $a l, 2005)$.

Berdasarkan data Laporan Riskesdas tahun 2013 pada remaja berdomisili di daerah perkotaan yang kurang mengkonsumsi buah dan sayuran sebesar 93,2\%, sedangkan remaja berdomisili di daerah pedesaan sebesar 95,3\%. Rendahnya konsumsi buah dan sayur tersebut dipengaruhi oleh beberapa faktor yang terdiri atas jenis kelamin, uang bulanan, tingkat pendidikan orang tua, pengetahuan buah dan sayur, kesukaan, kepercayaan diri, dukungan teman sebaya, ketersediaan buah dan sayur, keterpaparan media massa dan persepsi citra tubuh. Usia remaja akhir di daerah urban makanan yang lebih dipilih adalah makanan cepat saji, sedangkan responden di daerah rural lebih sering memilih buah, sayuran dan daging sebagai makanan favorit (Suliburska, et al., 2012).

Data Riskesdas DIY tahun 2013 menunjukkan rerata konsumsi buah penduduk umur 20-24 tahun sebesar 0,6 porsi/hari lebih rendah daripada rerata konsumsi jumlah porsi/hari buah DIY yaitu 0,7 porsi/hari. Hal tersebut tidak berbeda jauh dengan konsumsi sayur sebesar 1,6 porsi/hari lebih rendah daripada rerata konsumsi jumlah porsi/hari buah DIY yaitu 1,8 porsi perhari. Penelitian ini dilaksanakan di Universitas Negeri
Yogyakarta Fakultas (UNY) Fakultas Ilmu Pendidikan (FIP) Pendidikan Guru Sekolah Dasar (PGSD) yang terdiri dari dua lokasi yaitu di kota Yogyakarta sebagai perwakilan perkotaan (urban) dan di kabupaten Kulon Progo dan Bantul sebagai perwakilan daerah pedesaan (rural). Sebagian besar penelitian sebelumnya berfokus pada orang dewasa serta anakanak tanpa melihat latar belakang tempat tinggal di daerah rural atau urban.

Masa remaja dan dewasa awal adalah periode kehidupan yang penting karena para peneliti menyarankan bahwa kebiasaan diet di masa kanak-kanak atau remaja cenderung tetap sama di masa dewasa (Lien, 2001; Mikkila, 2004). Disamping itu dalam penelitian sebelumnya variabel buah dan sayur dijadikan satu, berbeda dengan penelitian ini yang memisahkan variable buah dan sayur yang dihubungkan dengan faktor individu dengan lingkungan. Oleh karena itu, kebiasaan konsumsi buah dan sayur dapat memiliki dampak yang lebih lama, dan dengan demikian, lebih signifikan terhadap kesehatan selama masa hidup. Beberapa penelitian sebelumnya tentang faktor-faktor yang berhubungan dengan konsumsi buah dan sayur pada remaja didapatkan hasil ada hubungan yang signifikan antara pengetahuan, ketersedian makanan, keterpaparan media, pendapatan orang tua (Rachman, 2017). Hasil penelitian ini dapat memberikan implikasi terhadap kebijakan kesehatan dengan memberikan bukti untuk mendorong konsumsi buah dan sayur pada masa remaja untuk meningkatkan kesehatan fisik dan mental di awal masa dewasa. 


\section{METODE}

Penelitian ini dilakukan pada bulan Mei 2017 menggunakan pendekatan kuantitatif dengan desain studi cross sectional. Populasi pada penelitian ini adalah remaja di Fakultas PGSD UNY, sampel penelitian yaitu 186 orang dibagi menjadi dua lokasi yaitu wilayah rural dan urban. Lokasi kampus yang berada di wilayah urban (Kota Yogyakarta) sebanyak 98 orang dan lokasi kampus yang berada di wilayah rural yaitu di Kabupaten Kulonprogo sebesar 98 orang. Pengambilan sampel dengan tehnik sampling probablitas: simple random sampling.

Pengumpulan data dilakukan dengan menggunakan data primer. Instrumen yang digunakan dalam penelitian adalah kuesioner. Kuesioner yang diisi sendiri oleh responden terdiri dari dua bagian. Bagian pertama adalah kuesioner yang berisi pertanyaan untuk mendapatkan gambaran mengenai karakteristik responden, pengetahuan gizi, kesukaan, media massa, dukungan teman sebaya (Farisa, 2012), pendidikan orang tua, citra tubuh, kepercayaan diri, uang bulanan, ketersediaan buah dan sayur, dan persepsi citra tubuh (Cornelia, 2015).Kuesioner bagian kedua adalah Food Frequency Questionnaire (FFQ) Uji coba kuesioner dilakukan kepada subjek. Berdasarkan hasil uji validitas tentang konsumsi sayur(r hitung>0,444). Berdasarkan hasil uji validitas tentang konsumsi buah yaitu 0,444dan uji realibilitas kuesioner buah didapatkan ( $\mathrm{r}$ hitung >0,444). Uji statistik yang digunakan pada penelitian ini adalah chi square test.
HASIL

Tabel 1. Distribusi Frekuensi Faktor Individu dan lingkungan konsumsi buah dan sayur di daerah rural dan urban

\begin{tabular}{|c|c|c|c|c|}
\hline \multirow[t]{2}{*}{ Karakteristik } & \multicolumn{2}{|c|}{ Rural } & \multicolumn{2}{|c|}{ Urban } \\
\hline & $\mathrm{n}$ & $\%$ & $\mathrm{n}$ & $\%$ \\
\hline \multicolumn{5}{|c|}{ Frekuensi konsumsi sayur } \\
\hline Kurang & 47 & 48 & 56 & 57,1 \\
\hline Cukup & 51 & 52 & 42 & 42,9 \\
\hline \multicolumn{5}{|c|}{ Frekuensi konsumsi buah } \\
\hline Kurang & 84 & 85,7 & 39 & 39,8 \\
\hline Cukup & 14 & 14,3 & 59 & 60,2 \\
\hline \multicolumn{5}{|l|}{ Jenis Kelamin } \\
\hline Laki-laki & 33 & 33,7 & 12 & 12,2 \\
\hline Perempuan & 65 & 66,3 & 86 & 87,8 \\
\hline \multicolumn{5}{|c|}{ Jumlah Uang Bulanan } \\
\hline Rendah & 46 & 46,9 & 45 & 45,9 \\
\hline Tinggi & 52 & 53,1 & 53 & 54,1 \\
\hline \multicolumn{5}{|l|}{ Pendidikan Ayah } \\
\hline Rendah & 22 & 22,4 & 26 & 26,5 \\
\hline Tinggi & 76 & 77,6 & 72 & 73,5 \\
\hline \multicolumn{5}{|l|}{ Kepercayaan Diri } \\
\hline Kurang & 48 & 49,0 & 43 & 43,9 \\
\hline Baik & 50 & 51,0 & 55 & 56,1 \\
\hline \multicolumn{5}{|l|}{ Dukungan Teman } \\
\hline Kurang Baik & 44 & 44,9 & 61 & 62,2 \\
\hline Baik & 54 & 55,1 & 37 & 37,8 \\
\hline \multicolumn{5}{|c|}{ Ketersediaan Buah dan Sayur } \\
\hline Kurang & 47 & 48,0 & 34 & 34,7 \\
\hline Cukup & 51 & 52,0 & 64 & 65,3 \\
\hline \multicolumn{5}{|c|}{ Keterpaparan Informasi } \\
\hline Kurang & 76 & 77,6 & 69 & 70,4 \\
\hline Sering & 22 & 22,4 & 29 & 29,6 \\
\hline \multicolumn{5}{|l|}{ Kesukaan Sayuran } \\
\hline Tidak suka & 16 & 16,3 & 32 & 32,7 \\
\hline Suka & 82 & 83,7 & 66 & 67,3 \\
\hline \multicolumn{5}{|l|}{ Kesukaan Buah } \\
\hline Tidak suka & 20 & 20,4 & 12 & 12,2 \\
\hline Suka & 78 & 79,6 & 86 & 87,8 \\
\hline \multicolumn{5}{|l|}{ Persepsi Citra Tubuh } \\
\hline Kurang & 26 & 26,5 & 20 & 20,4 \\
\hline Normal & 56 & 57,1 & 43 & 43,9 \\
\hline Gemuk & 16 & 16,3 & 35 & 35,7 \\
\hline \multicolumn{5}{|l|}{ Pengetahuan Gizi } \\
\hline Rendah & 12 & 12,2 & 28 & 21,4 \\
\hline Sedang & 55 & 56,1 & 49 & 50,0 \\
\hline Tinggi & 31 & 31,6 & 21 & 28,6 \\
\hline
\end{tabular}


Berdasarkan tabel 1 menunjukkan sebagai berikut: Frekuensi konsumsi sayuran yang kurang dari 3x per hari di daerah urban sebesar $57,1 \%$ lebih tinggi daripada di daerah rural sebesar $48 \%$. Sedangkan responden yang mengkonsumsi buah kurang dari $2 \mathrm{x}$ per hari di daerah rural sebesar $85,7 \%$ lebih tinggi daripada di daerah urban sebesar 39,8\%. Remaja yang berjenis kelamin perempuan banyak di daerah rural $66,3 \%$ dan urban $87,8 \%$ daripada remaja laki-laki. Jumlah uang saku pada remaja yang <Rp. 600.000,- per bulan tidak berbeda jauh dengan remaja didaerah rural sebesar $46 \%$ dan urban sebesar $45 \%$. Pendidikan orang tua lebih tinggi pada remaja yang tinggal didaerah rural $77,6 \%$ dibandingkan dengan remaja yang ayahnya memiliki tingkat pendidikan tinggi di daerah urban $73,3 \%$. Remaja di daerah rural memiliki kepercayaan diri yang kurang sebear 49\% lebih tinggi dibandingkan dengan kepercayaan diri pada remaja yang tinggal di daerah urban yaitu $43,9 \%$. Responden yang kurang mendapat dukungan teman pada remaja di daerah urban sebesar $62,2 \%$ tinggi dibandingkan dengan remaja didaerah rural sebesar $44,9 \%$. Ketersediaan buah dan sayur yang kurang lebih tinggi di daerah rural sebesar 47\% dibandingkan dengan daerah urban sebesar $34,7 \%$. Remaja yang kurang terpapar informasi mengenai konsumsi buah dan sayur di daerah rural lebih tinggi $77,6 \%$ dibandingkan dengan remaja yang tinggal di daerah urban 70,4\%. Responden yang tidak menyukai sayuran lebih tinggi didaerah urban sebesar $32,7 \%$ daripada di daerah rural sebesar $16,3 \%$. Remaja yang tidak menyukai buah yang berdomisi di daerah rural lebih tinggi sebesar 20,4\% daripada di daerah urban sebesar 12,2\%.
Remaja yang berdomisili di daerah rural $56(57,1 \%)$ dan urban $43(43,9 \%)$ merasa penampilan fisiknya dalam keadaan normal (Berat Badan Ideal), akan tetapi remaja di daerah urban merasa lebih gemuk sebesar $35(35,7 \%)$ lebih tinggi dibandingkan remaja di daerah rural yaitu $16(16,3 \%)$.

Pengetahuan berdasarkan kategori wilayah sebagai berikut skor pengetahuan tentang gizi konsumsi buah dan sayur pada remaja rural $31,6 \%$ lebih tinggi dibandingkan remaja urban $28,6 \%$.

Tabel 2. Hubungan Faktor individu dan Lingkungan dengan Konsumsi Sayuran di Daerah Rural tahun $2017(\mathbf{n}=98)$

\begin{tabular}{|c|c|c|c|c|c|c|c|c|}
\hline \multirow{3}{*}{$\begin{array}{c}\text { Variabel } \\
\text { Indepen-den }\end{array}$} & \multicolumn{8}{|c|}{ Konsumsi Sayuran } \\
\hline & \multicolumn{2}{|c|}{ kurang } & \multicolumn{2}{|c|}{ cukup } & \multicolumn{2}{|c|}{ Total } & \multirow{2}{*}{$\begin{array}{c}\mathrm{p}- \\
\text { value }\end{array}$} & \multirow[b]{2}{*}{ OR } \\
\hline & $\mathbf{n}$ & $\%$ & $\mathbf{n}$ & $\%$ & $\mathbf{n}$ & $\%$ & & \\
\hline \multicolumn{9}{|l|}{ Persepsi } \\
\hline \multicolumn{9}{|l|}{ Citra Tubuh } \\
\hline Kurang & 20 & 76,9 & 6 & 23,1 & 26 & 100 & \multirow{3}{*}{$\begin{array}{l}0,041 \\
*\end{array}$} & \\
\hline Normal & 24 & 42,9 & 32 & 57,1 & 26 & 100 & & \\
\hline Gemuk & 3 & 18,8 & 13 & 81,3 & 16 & 100 & & \\
\hline \multicolumn{9}{|l|}{ Pendidikan Ayah } \\
\hline Rendah & 32 & 42,1 & 44 & 57,9 & 76 & 100 & \multirow{2}{*}{$\begin{array}{l}0,031 \\
*\end{array}$} & \multirow[t]{2}{*}{2,946} \\
\hline Tinggi & 15 & 68,2 & 7 & 31,8 & 22 & 100 & & \\
\hline
\end{tabular}

Tabel 2. menunjukkan hasil uji statistik persepsi citra tubuh diperoleh nilai p-value 0,041 yang artinya ada hubungan persepsi citra tubuh dengan konsumsi sayuran di daerah rural. Hasil uji statistik diperoleh nilai p-value 0,031 yang artinya ada hubungan tingkat pendidikan ayah dengan konsumsi sayuran di daerah rural. Tidak ada hubungan yang signifikan Jenis kelamin $(p=0,474)$, Pengetahuan $(p=0,383)$, Kesukaaan $\quad(p=0,521)$ Uangbulanan ( $\mathrm{p}=0,323)$, Kepercayaan Diri $(\mathrm{p}=0,846)$, Ketersediaan $\quad(p=0,934) \quad$ Keterpaparan Informasi $(\mathrm{p}=0,793)$, Dukungan Teman $(\mathrm{p}=0,515)$ dengan konsumsi sayuran di daerah Rural. 
Tabel 3. Hubungan Faktor individu dan lingkungan dengan Konsumsi Sayuran di Daerah Urban tahun 2017 (n= 98)

\begin{tabular}{|c|c|c|c|c|c|c|c|c|}
\hline \multirow{3}{*}{$\begin{array}{c}\text { Variabel } \\
\text { Indepen- } \\
\text { den }\end{array}$} & \multicolumn{7}{|c|}{ Konsumsi Sayuran } & \multirow[b]{3}{*}{ OR } \\
\hline & \multicolumn{2}{|c|}{ kurang } & \multicolumn{2}{|c|}{ cukup } & \multicolumn{2}{|c|}{ Total } & \multirow{2}{*}{$\begin{array}{c}\mathrm{p}- \\
\text { value }\end{array}$} & \\
\hline & $\mathbf{n}$ & $\%$ & $\mathbf{n}$ & $\%$ & $\mathbf{n}$ & $\%$ & & \\
\hline \multicolumn{9}{|c|}{ Pengetahuan } \\
\hline Rendah & 12 & 42,9 & 16 & 57,1 & 28 & 100 & \multirow{3}{*}{$\begin{array}{l}0,047 \\
*\end{array}$} & \\
\hline Sedang & 34 & 69,4 & 15 & 30,6 & 49 & 100 & & \\
\hline Tinggi & 10 & 47,6 & 11 & 52,4 & 21 & 100 & & \\
\hline \multicolumn{9}{|l|}{ Persepsi } \\
\hline \multicolumn{9}{|c|}{ Citra Tubuh } \\
\hline Kurang & 17 & 85 & 3 & 25 & 20 & 100 & \multirow{3}{*}{\multicolumn{2}{|c|}{$\begin{array}{l}0,049 \\
*\end{array}$}} \\
\hline Normal & 21 & 48,8 & 22 & 51,2 & 43 & 100 & & \\
\hline Gemuk & 18 & 51,4 & 17 & 48,6 & 35 & 100 & & \\
\hline
\end{tabular}

Tabel 3. menunjukkan hasil uji statistik tingkat pengetahuan diperoleh nilai $\mathrm{p}$ value 0,047 yang artinya ada hubungan pengetahuan tentang buah dan sayuran dengan konsumsi sayuran di daerah urban. Hasil uji statistik persepsi citra tubuh diperoleh nilai p-value 0,049 yang artinya ada hubungan persepsi citra tubuh dengan konsumsi sayuran didaerah urban. Tidak ada hubungan yang signifikan Jenis kelamin ( $\mathrm{p}=0,824)$, Pengetahuan $(\mathrm{p}=0,383)$, Kesukaaan $(p=0,437)$, Uang Bulanan $(\mathrm{p}=0,298)$, Kepercayaan Diri $(\mathrm{p}=0,977)$, Pendidikan Ayah $(\mathrm{p}=0,869)$ Ketersediaan $(\mathrm{p}=0,502) \quad$ Keterpaparan Informasi $(\mathrm{p}=0,600)$, Dukungan Teman $(\mathrm{p}=0,787)$ dengan konsumsi sayuran di daerah Urban.

\section{Tabel 4. Hubungan faktor individu dan lingkungan dengan Konsumsi Buah di Daerah Rural tahun 2017 (n= 98)}

\begin{tabular}{|c|c|c|c|c|c|c|c|c|}
\hline \multirow{3}{*}{$\begin{array}{c}\text { Variabel } \\
\text { Indepen- } \\
\text { den }\end{array}$} & \multicolumn{8}{|c|}{ Konsumsi Buah } \\
\hline & \multicolumn{2}{|c|}{ kurang } & \multicolumn{2}{|c|}{ cukup } & \multicolumn{2}{|c|}{ Total } & \multirow{2}{*}{$\begin{array}{c}\text { p- } \\
\text { value }\end{array}$} & \multirow[b]{2}{*}{ OR } \\
\hline & $\mathbf{n}$ & $\%$ & $\mathbf{n}$ & $\%$ & $\mathbf{n}$ & $\%$ & & \\
\hline \multicolumn{9}{|l|}{ Persepsi } \\
\hline \multicolumn{9}{|l|}{ Citra Tubuh } \\
\hline Kurang & 26 & 100 & 0 & 0 & 26 & 100 & & \\
\hline Normal & 47 & 83,9 & 9 & 16,1 & 56 & 100 & 0,016 & \\
\hline Gemuk & 11 & 68,8 & 5 & 31,1 & 16 & 100 & $*$ & \\
\hline
\end{tabular}

Tabel 4. menunjukkan hasil uji statistik persepsi citra tubuh diperoleh nilai p-value 0,016 yang artinya ada hubungan persepsi citra tubuh dengan konsumsi buah di daerah rural. Tidak ada hubungan yang signifikan Jenis kelamin $(\mathrm{p}=0,131)$, Pengetahuan $\quad(p=0,745), \quad$ Kesukaaan ( $\mathrm{p}=1,000)$, Uang Bulanan $(\mathrm{p}=0,231)$, Kepercayaan Diri $(p=0,173)$, Pendidikan Ayah $(\mathrm{p}=0,181)$ Ketersediaan $(\mathrm{p}=0,367)$, Keterpaparan Informasi $(\mathrm{p}=1,000)$, Dukungan Teman $\quad(p=0,481)$ dengan konsumsi buah di daerah Rural.

Tabel 5. Hubungan Variabel Independen dengan Konsumsi Buah di Daerah Urban tahun $2017(\mathbf{n}=98)$

\begin{tabular}{|c|c|c|c|c|c|c|c|c|}
\hline \multirow{3}{*}{$\begin{array}{c}\text { Variabel } \\
\text { Indepen } \\
\text {-den }\end{array}$} & \multicolumn{8}{|c|}{ Konsumsi Buah } \\
\hline & \multicolumn{2}{|c|}{ kurang } & \multicolumn{2}{|c|}{ cukup } & \multicolumn{2}{|c|}{ Total } & \multirow{2}{*}{$\begin{array}{c}\mathrm{p}- \\
\text { value }\end{array}$} & \multirow[b]{2}{*}{ OR } \\
\hline & $\mathbf{n}$ & $\%$ & $\mathbf{n}$ & $\%$ & $\mathbf{n}$ & $\%$ & & \\
\hline \multicolumn{7}{|c|}{ Uang Bulanan } & \multirow{3}{*}{$0,006^{*}$} & \multirow{3}{*}{3,482} \\
\hline Rendah & 25 & $\begin{array}{l}55 \\
6\end{array}$ & 20 & 44,4 & 45 & 100 & & \\
\hline Tinggi & 14 & $\begin{array}{l}26, \\
4\end{array}$ & 39 & 73,6 & 53 & 100 & & \\
\hline
\end{tabular}

Tabel 5. menunjukkan hasil uji statistik diperoleh nilai p-value 0,006 maka dapat disimpulkan ada hubungan yang signifikan antara uang bulanan dengan konsumsi buah di daerah Urban. Tidak ada hubungan yang signifikan Jenis kelamin $(\mathrm{p}=0,534)$, Pengetahuan $\quad(p=0,051), \quad$ Kesukaaan $(\mathrm{p}=0,119)$, Persepsi Citra Tubuh $(\mathrm{p}=0,075)$ Kepercayaan Diri $(\mathrm{p}=0,872)$, Pendidikan Ayah $(p=0,314)$ Ketersediaan $(p=0,052)$ Keterpaparan Informasi $\quad(\mathrm{p}=0,535)$, Dukungan Teman $(\mathrm{p}=0,072)$ dengan konsumsi buah di daerah Urban.

\section{PEMBAHASAN}

Pada umumnya responden penelitian sebelumnya tidak menggambarkan konsumsi sayur dan buah di daerah rural 
dan urban, dalam penelitian ini melibatkan 98 responden dari daerah rural dan 98 responden dari daerah urban didapatkan hasil frekuensi konsumsi sayur yang kurang dari $3 \mathrm{x}$ per hari berada di daerah urban sebesar $57,1 \%$ lebih tinggi daripada di daerah rural sebesar $48 \%$, adapun frekuensi konsumsi buah diukur dengan FFQ berbeda dengan penelitian sebelumnya yang menggunakan Recall 24 jam. Hasil pengukurang frekuensi yang kurang dari $2 \mathrm{x}$ per hari di daerah rural sebesar $85,7 \%$ lebih tinggi daripada di daerah urban sebesar 39,8\%. Konsumsi sayur lebih tinggi pada responden di daerah rural dikarenakan sebagian besar responden tinggal bersama keluarga, sehingga dalam pengaturan menu masih melibatkan orang tua terutama ibu, selain itu masyarakat di kabupaten Kulon Progo memiliki pekarangan yang bisa ditanam sayuran tertentu, sehingga kebutuhan sayuran dapat tercukupi.

Konsumsi buah cenderung lebih tinggi di daerah Urban yaitu di wilayah pusat kota Daerah Istimewa Yogyakarta hal ini dikarenakan ketersediaan buah yang dapat dijangkau dengan mudah. Meskipun mahasiswa mengonsumsi buah seperti rujak, lotis dan buah potong, oleh karena itu konsumsi buah lebih tinggi pada responden di daerah urban. Selain itu buah dan sayur seringkali dianggap sebagai bahan makanan yang tidak bergengsi untuk dikonsumsi sehingga remaja cenderung tidak mengkonsumsi buah dan sayur justru remaja lebih memilih bahan makanan yang lainnya seperti makanan cepat saji. Dari segi kepraktisan remaja akan lebih memilih mengkonsumsi fast food dibanding buah dan sayur karena terbatasnya waktu dan tingginya tingkat kesibukan yang mereka miliki seperti kegiatan di kampus dan di luar kampus. Dalam peneltian sebelumnya tidak melakukan peneltian dalam factor individu mapun faktor lingkungan. Dalam penelitian ini faktor individu dan faktor lingkungan yang diteliti adalah jenis kelamin, kesukaan, keyakinan diri,pengetahuan gizi, dukungan teman, ketersediaan buah dan sayur, persepsi citra tubuh.

Hasil analisis hubungan jenis kelamin dengan konsumsi sayuran dan buah didaerah rural dan urban menunjukkan tidak ada hubungan yang signifikan, hal tersebut dikarenakan jumlah responden laki-laki lebih sedikit baik di daerah rural dan urban dibandingkan jumlah responden perempuan, sehingga proporsi pada tabulasi silang tidak menunjukkan adanya hubungan yang bermakna. Meskipun begitu responden laki-laki baik yang tinggal di daerah rural dan urban cenderung lebih sedikit mengkonsumsi buah dan sayur dibandingkan responden perempuan. Penelitian ini didukung (Wind, 2010) lebih sedikit anak dilaporkan mengkonsumsi sayuran setiap hari dibandingkan buah. Untuk frekuensi perbedaan gender ditemukan, dengan lebih banyak anak perempuan daripada anak laki-laki yang dilaporkan makan buah (p <0,05) dan sayuran $(\mathrm{p}<0,001)$ setiap hari.

Ada hubungan pengetahuan tentang buah dan sayuran dengan konsumsi sayuran di daerah urban. Hal ini dikarenakan sebagian besar skor pengetahuan tentang gizi sayur dan buah termasuk dalam kategori sedang di daerah rural sebesar 55(56,1\%) dan urban 49(50\%). Pengetahuan merupakan suatu landasan kognitif untuk terbentuknya sikap, termasuk sikap dan perilaku seseorang dalam pemilihan makanan, selain itu responden yang berpengetahuan gizi 
lebih baik lebih mudah dalam memilih dan mengolah makanan yang sesuai kebutuhannya. Menurut Jane(2015) kecenderungan responden dengan pengetahuan buah dan sayur yang tinggi mengonsumsi buah dan sayur lebih banyak 1,282 kali daripada responden dengan pengetahuan buah dan sayur yang rendah

Hasil uji chi-square menunjukkan tidak ada hubungan kesukaan dengan konsumsusi buah dan sayur baik didaerah rural maupun urban. Dalam penelitian ini responden di wilayah rural yang menyatakan kesukaan terhadap buah sebesar $87,8 \%$ sedangkan yang tidak suka sebesar 12,2\%.Dari 12 responden yang menyatakan tidak suka terhadap buah, paling banyak tidak suka buah karena mahal (41.7\%). Dari 86 responden yang menyatakan suka terhadap buah, alasan paling banyak konsumsi buah karena sumber vitamin (54.7\%). Adapun konsumsi buah didaerah urban hasilnya yang menyatakan suka sebesar 79,6\% dari 76 responden yang menyatakan suka terhadap buah, alasan paling banyak konsumsi buah karena rasanya segar(51.3\%), dan yang tidak menyukai sebesar 20,4\% dari 20 responden yang menyatakan tidak suka terhadap buah, paling banyak tidak suka buah karena malas membeli (45.0\%). Kesukaan sayuran pada responden yang tinggal di daerah rural sebesar $83,7 \%$ dengan alasan karena sayuran merupakan sumber serat yang penting bagi tubuh untuk mencegah penyakit. Responden yang tidak suka sayuran sebesar $16,3 \%$ dengan alasan mereka tidak menyukai sayuran karena rasanya yang tidak enak $(62,5 \%)$. Alasan tersebut serupa dengan responden yang tinggal didaerah urban.
Uji statistik menunjukkan ada hubungan uang bulanan dengan konsumsi buah di daerah urban diperoleh nilai p-value 0,003. Konsumsi buah yang cukup lebih banyak pada responden yang uang bulananya lebih dari Rp.600.000,-. Apabila terjadi kenaikan pengeluaran maka konsumsi buah oleh responden juga akan meningkat. Hal tersebut sejalan dengan penelitian Azagba(2011) pada remaja dan orang dewasa di Australia dikatakan ada hubungan yang positif antara pendapatan dengan konsumsi buah dan sayur.

Ada hubungan persepsi citra tubuh dengan konsumsi sayuran di daerah rural maupun urban, selain itu ditemukan hubungan yang signifikan antara persepsi citra tubuh dengan konsumsi buah di daerah rural. Hasil penelitian tersebut sesuai dengan penelitian Ham dan Kim (2014) dimana jumlah asupan buah ketika malam hari memiliki hubungan signifikan dengan berat badan dan BMI. Remaja yang memiliki persepsi status gizi gemuk menginginkan bentuk tubuh yang lebih langsing. Remaja yang berstatus gizi gemuk atau obes sedang menjalani pengurangan konsumsi makan untuk mengurangi berat badan. Adapun remaja yang persepsi dirinya sedang atau normal menyatakan menghindari atau mengurangi untuk mengonsumsi makanan berminyak, berlemak dan daging untuk menjaga bentuk tubuh yang diinginkan. Hal berkebalikan terjadi pada beberapa remaja yang berstatus gizi gemuk, mereka tetap memilki persepsi positif terhadap makanan dan mersa tidak perlu untuk menghindari mengkonsumsi sesuatu untuk mendapatkan bentuk tubuh yang diinginkan, selama mengkonsumsi makanan tidak berlebihan (Desita, 2013). 
Tidak ada hubungan yang siginifikan dalam kepercayaan diri pada remaja baik di daerah rural maupun di daerah urban dapat diakibatkan sebagian besar responden memiliki kepercayaan diri yang negatif dalam mengonsumsi buah dan sayur sehingga hasilnya tidak signifikan dalam penelitian ini. Individu yang memiliki kepercayaan diri negatif akan mempercayai bahwa mereka tidak mampu melakukan apapun, akibatnya mereka memiliki kemampuan yang rendah untuk mengatasi masalah. Individu yang memilki kepercayaan diri yang tinggi akan segera mengambil inisiatif untuk mengadopsi perilaku hidup sehat. Misalnya masalah kegemukan menimbulkan pengambilan keputusan yang berkaitan dengan perilaku hidup sehat ataupun perilaku ketaan menjalankan program diet. Berdasarkan data pengukuran IMT pada responden sebagian besar responden baik di daerah rural maupun urban termasuk dalam rentang normal/sedang sehingga berpengaruh dalam kepercayaan diri responden karena merasa berat badannya normal sehingga tidak perlu untuk diet tinggi sayur dan buah.

Ada hubungan tingkat pendidikan orang tua dengan konsumsi sayuran. Hal ini disebabkan karena berdasarkan data distribusi frekuensi responden yang memilki ayah dengan pendidikan tinggi lebih banyak di daerah rural sebesar $76 \%$ didaerah rural dan $72 \%$ di daerah urban. Hasil penelitian ini didukung penelitian Pearson (2010) ada hubungan positif antara status pekerjaan orang tua dan konsumsi buah remaja dan antara pendidikan orang tua dan konsumsi buah dan sayur pada remaja. Beberapa variabel yang kuat dalam mempengaruhi perilaku makan dalam keluarga atau rumah tangga meliputi unsur- unsur pekerjaan kepala keluarga, jumlah anak, pendidikan, dan sebaginya. Tingkat pendidikan dalam penelitian ini yang diteliti adalah tingkat pendidikan ayah, karena di dalam budaya Jawa masih memegang budaya Patriarkhi, dimana Ayah berperan sebagai pengambil keputusan dalam kehidupan berumah tangga. Pengambilan keputusan terutama dalam perilaku makan dapat dipengaruhi oleh tingkat pendidikan ayah dimana semakin tinggi tingkat pendidikan ayah akan menentukan pendapatan keluarga. Dengan meningkatnya pendapatan seseorang maka terjadilah perubahanperubahan dalam susunan makanan. Begitu pula dengan kebiasaan makan yang cenderung berubah bersama dengan naiknya pendapatan. Hasil penelitian diatas sejalan dengan hasil penelitian McKinney (2013) pengetahuan gizi dan pendidikan secara keseluruhan menunjukkan secara positif dalam memberikan pengaruh pada kebiasaan makan, misalnya, orang dewasa dengan gelar sarjana lebih tinggi maka asupan buah dan sayuran lebih daripada individu tanpa gelar sarjana.

Tidak terdapat hubungan yang signifikan ketersediaan sayur dan buah dengan konsumsi buah dan sayur didaerah rural maupun urban. Hal tersebut dapat terjadi karena ada faktor lain yang mempengaruhi ketersediaan buah dan sayur. Dari hasil tabulasi silang pendidikan tinggi pada orang tua dan uang bulanan responden tinggi. Hasilnya pendapatan tinggi dapat meningkatkan daya beli keluarga khususnya dalam membeli buah dan sayur sehingga dapat mendukung ketersediaan buah dan sayur pada remaja di daerah rural dan urban. Hasil penelitian diatas berbeda dengan penelitian Rakhshanderou (2014) dalam tinjauan literatur factor penentu yang 
utama asupan buah dan sayuran pada anakanak dan remaja dilaporkan bahwa dua dari tiga makalah mengidentifikasi hubungan positif antara ketersediaan buah dan sayuran. Dari semua faktor penentu dalam penelitian yang dilakukan oleh Blanchette dan Brug (2010), ketersediaan dan aksesibilitas buah dan sayuran paling konsisten dan memiliki hubungan yang positif terkait dengan konsumsi. Ketersediaan buah dan sayuran di rumah tergantung pada beberapa faktor misalnya, Status keuangan, waktu, dan pentingnya kesehatan remaja, dari sudut pandang orang tua). Aksesibilitas merupakan faktor yang lebih penting daripada ketersediaan, karena menyiapkan buah dan sayuran untuk digunakan (mencuci, mengiris, dll.) adalah penghalang utama yang telah disebutkan oleh remaja. Secara umum, terlepas dari ketersediaan, remaja dapat menahan diri dari mengkonsumsi buah dan sayuran karena kurangnya keterampilan menyiapkan buah dan sayur (Rakhshanderou, 2014).

Tidak terdapat hubungan keterpaparan media dengan konsumsi buah dan sayur baik di daerah rural maupun urban. Hal tersebut dikarenakan remaja yang kurang terpapar informasi mengenai konsumsi buah dan sayur di daerah rural lebih tinggi $77,6 \%$ dibandingkan dengan remaja yang tinggal di daerah urban 70,4\%. Dalam penelitian ini responden menyatakan bahwa media yang paling sering terpapar oleh responden adalah media internet. Hasil penelitian di atas sejalan dengan penelitian lain, ditemukan bahwa iklan/media massa tidak berpengaruh secara signifikan terhadap perilaku konsumsi individu (Srimaryani, 2010).
Hasil uji statistik menunjukkan ada hubungan dukungan teman dengan konsumsi buah didaerah urban . Hal tersebut dikarenakan remaja di daerah urban mendapat dukungan baik dari teman sebesar $73 \%$. Responden yang kurang mendapat dukungan teman berisiko 2,4 kali mengkonsumsi buah kurang dari $2 \mathrm{x}$ per hari. Pengaruh rekan atau kelompok sebaya sangat kuat. Ketika anak mulai sekolah tekanan teman sebaya mulai mempengaruhi pemilihan makanan yang menyebabkan pengabaian terhadap kebutuhan gizi. Remaja mulai peduli terhadap penampilan fisik dan perilaku sosial, serta berusaha untuk mendapatkan penerimaan dari teman sebayanya. Pemilihan makanan menjadi penting supaya mereka diterima oleh teman sebayanya. Teman sebaya berpengaruh secara signifikan terhadap perilaku konsumsi individu, yaitu dalam memilih jenis makanan, seseorang akan mengikuti teman sebayanya (Savitri, 2009). Hal tersebut didukung dalam penelitian Bruening (2012), ada hubungan yang signifikan kebiasaan konsumsi sayur antara remaja dan sahabatnya $(\mathrm{p}=0,038)$. Konsumsi buah dan sayuran pada saat persiapan makan malam diasosiasikan dengan kebiasaan melihat dari teman ( $\mathrm{p}<$ 0.001) (Pelletier, 2014).

\section{KESIMPULAN}

1. Frekuensi konsumsi sayuran yang kurang dari 3x per hari di daerah urban sebesar $57,1 \%$ lebih tinggi daripada di daerah rural sebesar $48 \%$. Sedangkan responden yang mengkonsumsi buah kurang dari 2x per hari di daerah rural sebesar $85,7 \%$ lebih tinggi daripada di daerah urban sebesar 39,8\%.

2. Terdapat hubungan yang signifikan antara konsumsi sayuran pada remaja didaerah rural dengan tingkat 
pendidikan ayah $(\mathrm{p}=0,031)$ dan persepsi citra diri $(\mathrm{p}=0,041)$, adapun di daerah urban ada hubungan yang signifikan antara konsumsi sayuran dengan persepsi citra diri $(\mathrm{p}=0,049)$ dan pendidikan pada remaja $(\mathrm{p}=0,047)$. Konsumsi buah pada remaja di daerah rural yang berhubungan signifikan adalah persepsi citra tubuh $(\mathrm{p}=0,016)$, sedangkan pada remaja di daerah urban yang berhubungan secara signifikan adalah uang bulanan $(\mathrm{p}=0,003)$.

3. Saran yang dapat diberikan yaitu perawat bekerjasama dengan institusi pendidikan memberikan pendidikan kesehatan tentang pentingnya manfaat sayur dan buah. Untuk penelitian selanjutnya lebih dikembangkan faktor dominan konsumsi sayur dan buah pada remaja di daerah rural-urban.

\section{DAFTAR PUSTAKA}

Azagba, S., Sharaf, M. F. (2011). Disparities in the frequency of fruit and vegetable consumption by socio-demographic and lifestyle characteristics in Canada. Nutrition Journal.

Blanchette, L., \& Brug, J. (2010). Determinants of fruit and vegetable consumption among 6-12-year-old children and effective interventions to increase consumption. J Hum Nutr Diet, $18,431-43$.

Bruening, M, et al. (2012). Relationship between adolescents and their friends eating behaviours: breakfast, fruit and vegetable, whole-grain and dairy intake. Journal of the Academy of Nutrition and Dietetics, 112(12), 1608-1613.

Cornelia, J. (2015). Faktor-faktor yang berremaja dengan konsumsi buah dan sayur pada remaja ikatan remaja Riau Universitas Indonesia, Depok tahun
2015. Skripsi Jakarta: Gizi Kesehatan Masyarakat FKM Universitas Indonesia.

Desita, D. S. (2013) Analisis hubungan persepsi diri dan makanan, konsumsi pangan dan status gizi remaja usia Sekolah Menengah di Kabupaten Bogor. Institut Pertanian Bogor.

Ham Eunah \& Kim Hyun-Jin. (2014). Evaluation of fruit intake and its relation to body mass index of adolescents. Clinical Nutrition Research.http://dx.doi.org/10.7762/cnr.2 014.3.2.126.

Kemenkes RI. (2013). Riset kesehatan dasar; RISKESDAS. Jakarta: Balitbang Kemenkes RI.

Kemenkes RI. (2013). Riset kesehatan dasar dalam angka provinsi daerah istimewa yogyakarta Tahun 2013. Jakarta: Balitbang Kemenkes RI.

Lien, N., Lytle, LA., \& Klepp, KI. Stability in consumption of fruit, vegetables, and sugary foods in a cohort from age 14 to age 21. (2001). Prev Med, 13, 217-226. doi: 10.1006/pmed.2001.0874.

Mikkilä, V., Räsänen, L., Raitakari, OT., Pietinen, P., \& Viikari, J. (2004). Longitudinal changes in diet from childhood into adulthood with respect to risk of cardiovascular diseases: the cardiovascular risk in young Finns study. Eur J Clin Nutr. 13, 1038-1045. doi: 10.1038/sj.ejcn.1601929.

McKinney, C. (2013). Assessment of dietary behaviors of college students participating in the health promotion program BUCS: Live well. (Master thesis). Retrieved from East Tennessee State University.

Pelletier, J., Graham, D., \& Laska, M., (2014). Social norms and dietary behaviours among young adult. A.m J. Health Behav. doi 10.5993/ASHB. 38,1,15.

Pearson, N., Biddle S.J.H., \& Gorely T. (2010) Family correlates of fruit and vegetable 
consumption in children and adolescents: a systematic review.

Public Health Nutrition. https://doi.org/10.1017/S1368980008002 589.

Rachman, Bella N., Mustika I Gede., \& Kusumawati I.G.A Wita. (2017). Faktor yang berhubungan dengan perilaku konsumsi buah dan sayur siswa SMP di Denpasar. Jurnal Gizi Indonesia.ejournal.undip.ac.id/index.php /jgi/article/viewFile/17749/12608.

Rakhshanderou, S., Ramezankhani, A., Mehrabi, Y., \& Ghaffari, M., (2014) Determinants of fruit and vegetable consumption among Tehranian adolescents: A qualitative research. J Res Med Sci, 19(6), 482-489.

Savitri \& Rahma. (2009). Faktor-Faktor yang berhubungan dengan perilaku konsumsi makanan jajanan yang mengandung pewarna sintetik pada siswa kelas VIII dan IX Sekolah Menengah Pertama (SMP) PGRI 1 dan SMP YMJ Ciputat Tahun 2009. Skripsi. Jakarta: Kesehatan Masyarakat FKIK UIN Syarif Hidayatullah.

Srimaryani, D. I. (2010). Pola konsumsi pangan dan status gizi pada rumah tangga peserta program pemberdayaan masyarakat di Kota dan Kabupaten Bogor. Skripsi. Bogor: IPB.

Suliburska, J., Bogdanski, P., Pupek Musialik, D., Gold-Nawrocka, M., Krauss, H., ... Piatek, J., (2012) Analysis of lifestyle of young adult in the rural and urban areas. Annals of Agriculturural and Enviromental Medicine.

Wind, M., Vea, O., Franchini, B., Vaz de Almeida, MD., \& Klepp K. (2010). Gender and regional variation in fruit and vegetable consumption and determinants among 11- to 13 - year old Portuguese children. Journal of Nutrition. 
44 | Jurnal Keperawatan Raflesia, Volume 1 Nomor 1, Mei 2019

\section{HALAMAN INI SENGAJA DI KOSONGKAN}

